\title{
Visto desde Francia...
}

\author{
Alain Morel *; Philippe Batel ** \\ * Secrétaire Général de la Fédération Française d’Addictologie \\ ** Vice Président de l'Association des Équipes de Liaison et de Soins en Addictologie. \\ Enviar correspondencia a: \\ Philippe Batel. Psychiatre-Addictologue. Chef de I'Unité de Traitement Ambulatoire des Maladies Addictives (UTAMA) \\ Hôpital Beaujon 100, Boulevard du Général Leclerc 92110 Clichy Cedex FRANCE \\ Tel. 331408752 96, Fax 331408758 42, Cell 336609331 36, philippe.batel@bjn.aphp.fr
}

$\mathbf{N}$ ick Heather es conocido en Francia y en el resto del mundo como uno de los "popes" de la reducción del riesgo de alcohol. Pionero en la intervención breve en medicina comunitaria y en la medicina general, ha contribuido junto con otros colegas a validar la pertinencia y sobre todo a difundir el principio en numerosos países; por lo menos en los países occidentales sensibles al impacto del consumo de alcohol en la sanidad pública. Este es el motivo por el cual el verdadero reproche de este experto internacional sobre riesgo de alcohol se alza contra la política de salud pública de su gobierno en materia de alcohol y confirma claramente que "nadie es profeta en su tierra".

La situación que Nick Heather denuncia es en efecto inquietante. El análisis que realiza sobre la reacción del gobierno Blair al aumento en el consumo de alcohol británico y sus daños relativos (sin duda el aumento de la mortalidad atribuible) lo lleva a juzgar esta política no solamente como inapropiada y tardía sino sobre todo como peligrosa. Las decisiones de este gobierno han consistido básicamente en aumentar las horas en las que los pubs están autorizados a vender bebidas alcohólicas, y a desarrollar paralelamente una "estrategia de disminución de daños de alcohol en Inglaterra". A pesar de que las condiciones del problema del alcohol en Francia son sensiblemente diferentes de las de Gran Bretaña, nos encontramos en el deconstrucción de la política británica hecha por Nick Heather los mismos errores cometidos en nuestro país. Estos son de tres órdenes:

1) Negar lo que ha sido científicamente probado pero que no es muy popular: para tratar sobre la mortalidad específica relacionada con el alcohol de una población, es necesario disminuir el consumo global de ésta. En Francia, el objetivo de reducción del consumo global es ferozmente combatido por la industria alcoholera que sólo ven una reducción de su negocio. Es verdad que después de cuarenta años el consumo medio de vino ha disminuido a la mitad, lo que ha complicado sin duda el contexto económico de ciertos viticultores, pero que sobre todo ha representado paralelamente una disminución importante de las principales enfermedades graves producidas por el alcohol.

2) Evitar actuar con los medios que han sido eficaces: subir los impuestos, limitar la publicidad y la disponibilidad del alcohol por ejemplo. En Francia tampoco los responsables políticos demuestran valor y no toman medidas en este sentidol a título de ejemplo, las cervezas de alta graduación no tienen más impuestos que las otras y se venden en las estaciones de servicio de las carreteras y de las autopistas...)

3) Actuar en trampantojo, en particular transfiriendo la competencia del control y la limitación del consumo de alcohol de los magistrados hacía comités más permeables a los intereses locales e industriales. En nuestro país el lobby del alcohol (industriales y parlamentarios) ha logrado que el Gobierno cree un comité titulado "Consejo de la moderación" dónde tienen mucha fuerza para controlar las campañas de prevención que publica el Instituto Nacional de la Prevención y la Educación para la Salud (INPES) u otros organismos de salud pública. Seguramente todas las asociaciones de profesionales de salud en adictología van a boicotear este Consejo.

Por lo tanto desde el punto de vista de numerosos profesionales franceses, se podrían llegar a compromisos si los responsables políticos aceptaran abordar esta cuestión, prioritariamente desde el ángulo de la salud, así como se hace en muchos otros campos, como la seguridad vial: no se trata de impedir a la gente a utilizar su coche, pero hacerlo de una forma que disminuya los riesgos. Pensamos igualmente que no debería haber oposición entre la "prevención universal" que trata de disminuir el consumo global de la población general y las estrategias de reducción de 
riesgo más dirigidas a grupos concretos, la prevención "selectiva" o "indicada" en determinadas situaciones o para ciertas poblaciones (mujeres embarazadas, adolescentes, etc) para retomar las categorías del Observatorio Europeo de Drogas y Toxicomanías. Estos dos ejes de prevención son tan eficaces e indispensables el uno como el otro.

La situación del Reino Unido recuerda la de otros países europeos y sobre todo la del nuestro. El tiempo de reacción del mundo político de cara a la amenaza de la salud pública relacionada con el consumo excesivo de alcohol y su interferencia con la protección de lobbies alcoholeros que buscan sistemáticamente minimizarla, no es patrimonio de los sujetos de su majestad. La débil inversión de la política pública de reducción de riesgo y la ausencia de un plan general que financie la intervención breve la encontramos en la mayoría de países europeos. La asignación del dossier del alcohol al Ministerio encargado de la cultura, de la comunicación y del deporte es una aberración que casi nos produce risa; se lo encuentra muy a menudo en agricultura en los países productores.
Tres fenómenos específicos a la cultura británica merecen ser subrayados:

1) la alta frecuencia del beber compulsivo (binge drinking), especialmente en mujeres que son probablemente en parte responsables de la frecuencia del emborrachamiento público.

2) Las modificaciones del tipo de bebida (de la cerveza al vino) son radicalmente opuestas a las observadas en el sur de Europa.

3) La institución del pub y el impacto muy particular de sus horarios de apertura sobre el consumo.

Hace ya unos meses que el parlamento francés intentaba, por razones electorales, contestar a la crisis vitícola volviendo a poner en proceso la ley de salud pública elaborada por Claude Evin en 1991. Nick Heather firmaba con otros colegas en el gran periódico francés Le Monde un artículo rindiendo homenaje a la pertinencia de esta ley. Nosotros le deseamos vivamente ser el Claude Evin del Reino Unido para que encuentre un eco político a su legítima cólera. 